\title{
School Tracking and Access to Higher Education Among Disadvantaged Groups
}

\author{
Ofer Malamud \\ University of Chicago and NBER
}

\author{
Cristian Pop-Eleches* \\ Columbia University, BREAD, NBER
}

May 2008

\begin{abstract}
When students are tracked into vocational and academic secondary schools, access to higher education is usually restricted to those who were selected into the academic track. Postponing such tracking may increase the relative educational attainment of disadvantaged students if they have additional time in school to catch up with their more privileged counterparts. On the other hand, if ability and expectations are fairly well set by an early age, postponing tracking during adolescence may not have much effect. This paper exploits an educational reform in Romania to examine the impact of postponing tracking on the proportion of disadvantaged students graduating from university using a regression discontinuity (RD) design. We show that, although students from poor, rural areas and with less educated parents were significantly more likely to finish an academic track and become eligible to apply for university after the reform, this did not translate into an increase in university completion. Our findings indicate that simply postponing tracking, without increasing the slots available in university, is not sufficient to improve access to higher education for disadvantaged groups.
\end{abstract}

*Email: malamud@uchicago.edu and cp2124@columbia.edu respectively. We would like to thank Steve Pischke and Miguel Urquiola for helpful comments. All errors are our own. 


\section{Introduction}

The relationship between family background and access to higher education is a robust empirical finding across many countries. ${ }^{1}$ Yet there is debate about whether this relationship is mostly predetermined at an early age or can be mediated through investments in schooling. Carniero and Heckman $(2002,2003)$ argue that long-run factors shape ability and expectations early on and therefore emphasize the importance of early childhood investments. On the other hand, Krueger (2003) contends that the return to human capital investments remains high even beyond adolescence, and especially for those from less advantaged family backgrounds. But how important is age? Can the relationship between family background and access to higher education be influenced by the timing of educational transitions in secondary school? This paper exploits a unique educational reform in Romania which postponed when students were tracked into academic and vocational schools in order to examine whether such later tracking improves access to higher education among socio-economically disadvantaged children. ${ }^{2}$

The Romanian educational reform, which occurred in 1973, prevented students from entering vocational schools after only 8 years of schooling and, instead, required them to receive an additional two years of academic curriculum. Due to this policy change, students born after January 1, 1959 were more likely to complete an academic high school curriculum as compared to their counterparts who were born immediately before this date. By increas-

\footnotetext{
${ }^{1}$ Shavit and Blossfeld (1993) provide evidence from thirteen countries at various levels of development.

${ }^{2}$ In earlier work, we focused on whether the increased exposure to general education in academic schools affected labor market outcomes later in life (Malamud and Pop-Eleches, 2006). We provided evidence that the educational reform did not lead to an increase in average years of schooling or an increase in the proportion of students completing university. In this paper, we focus on access to higher education among socio-economically disadvantaged students.
} 
ing the fraction of students who completed academic high school, the reform also increased the proportion of students who became eligible to apply to university, while the number of mandated university slots remained unchanged. Using data from the Romanian Census, we employ a regression discontinuity $(\mathrm{RD})$ design to show that students from poor and rural regions and from less educated families, who were less likely to complete university, were also those most affected by the policy. However, although individuals from these groups were significantly more likely to be eligible for university after the reform, this did not translate into a relative increase in university graduation. If more time in academic schools had enabled disadvantaged students to catch up with their privileged counterparts, delaying the timing of tracking should have increased university completion among the disadvantaged. Instead, our findings indicate that simply postponing tracking, without increasing the number of slots available in university, is not sufficient to improve access to higher education for disadvantaged students. ${ }^{3}$

Many countries track pupils into academic and vocational schools at some point during their secondary education. ${ }^{4}$ One of the main arguments for tracking is that it is easier to teach a homogenous group of students. Duflo, Dupas, and Kremer (2007) argue that this explains the positive benefits of within-school tracking on achievement in Kenya. On the other hand, the possibility of positive spillover effects from more able to less able students is a common argument against tracking. Early tracking may also be inefficient when ability

\footnotetext{
${ }^{3}$ Although it is inherently difficult to define, the term "access to higher education" is often taken to mean college attendance. In the case of Romania, drop-out rates during the Communist period were so low that college attendance and college completion were essentially identical. (Braham, 1978)

${ }^{4}$ These include countries such as Austria, Germany, and Hungary. In contrast, Canada, Japan and the United States do not track students across different schools (though often have some ability tracking within schools).
} 
is measured with noise because some students may end up assigned to the wrong track. ${ }^{5}$ For Germany, Dustmann (2004) shows that parental background is strongly related to the secondary track choice of the child, and to subsequent educational achievements. Based on this evidence, Dustmann suggests that early tracking may explain the low levels of intergenerational mobility in Germany. Nevertheless, in the absence of any exogenous variation in the timing of tracking, it is difficult to provide truly compelling evidence. Manning and Pischke (2006) evaluate several studies in England and Wales which estimate the effect of moving from a system of extensive tracking to one with comprehensive schools on academic achievement but conclude that selection bias is a serious threat to validity and urge caution when interpreting results. ${ }^{6}$ In a cross-country setting, Hanushek and Wössman (2006) find evidence that tracking raises educational inequality but Waldinger (2006) argues that these results are not particularly robust to alternative specifications. Taking advantage of the unique educational reform in Romania, we use a regression discontinuity design to address the possibility of omitted variable bias and selection bias. Although Romania's labor market under Communism was structured rather differently from those in other countries, the education system was actually quite similar with a national curriculum and competitive entry into high school and university.

We also contribute to a growing literature which examines the impact of educational reforms in postwar Europe, and Scandinavia in particular. Meghir and Palme (2005) examine a Swedish reform which increased compulsory schooling, abolished selection, and introduced

\footnotetext{
${ }^{5}$ See Brunello, Giannini, and Ariga (2006) for an explicit model of the "noise" effect associated with early tracking.

${ }^{6}$ Maurin and McNally (2007) examine a more recent educational reform in 1989 that widened access to the academic track in Northern Ireland.
} 
a nationally unified curriculum. Exploiting a period of experimentation across municipalities during the 1950s, they find that the reform increased educational attainment and earnings for students from low SES families. Aakvik, Salvanes, and Vaage (2003) examine a similar reform in Norway which extended compulsory schooling, introduced comprehensive schools and established a common curriculum in the 1960s. Although they focus on estimating returns to schooling, they also find that the reform increased the probability of attending university and weakened the effect of family background on the likelihood of participating in higher education. Pekkarinen, Uusitalo, and Pakkala (2006) show that an analogous reform in Finland significantly decreased the intergenerational income elasticity. Nevertheless, it is difficult to isolate the effect of tracking in the earlier work because most of the educational reforms affected both the amount of education and the timing of selection. ${ }^{7}$ In the case of Romania, average years of schooling attained by students remained the same before and after the 1973 educational reform.

The paper is organized as follows. Section 2 provides a background of the Romanian educational system and the 1973 educational reform. Section 3 describes these data and the empirical strategy. Section 4 presents the results, and Section 5 concludes.

\footnotetext{
${ }^{7}$ For example, Meghir and Palme (2005, p. 418) note that "it is not possible to say which aspect of the reform led to the earnings gains...since both the amount of education and the quality/type of education changed for individuals."
} 


\section{Background}

\section{$2.1 \quad$ Education in Romania}

Apart from the changes induced by the 1973 reform, the structure of education in Romania throughout the 1970s was relatively stable. Students began compulsory schooling by entering schools of general education (scoală de cultură general $\breve{a})$ at the age of $6 .^{8}$ More specifically, students entered grade 1 in September of the year following the calendar year in which they reached 6 years of age. Since the mid-1950's, these schools offered 8 years of general education, nominally composed of primary education from grades 1 to 4 and gymnasium education from grades 5 to $8 .^{9}$ Prior to the educational reforms of 1973 , students who graduated from schools of general education entered vocational schools and apprenticeship programs or continued onto secondary school lyceums.

Entry into the different educational tracks after gymnasium was based on competitive entrance exams. The most prestigious secondary schools included academic lyceums (licee teoretice si real-umaniste), teacher training lyceums (licee pedagogice) and economic lyceums (licee economice), followed by the lower ranked industrial lyceums (licee industriale) and agricultural lyceums (licee agricole). Vocational schools (şcoli profesionale) were the least competitive schools and they provided training in numerous trades ranging from aircraft maintenance to winemaking. They operated at two levels: a lower vocational track for students who had completed 8 years of general education and an upper vocational track for students who had received an additional two years of general education in the first level of

\footnotetext{
${ }^{8}$ Preschool education was offered in kindergartens for children ranging from 3 to 6 years of age.

${ }^{9}$ Some general schools also included grades 9 and 10 (ciclul superior de 2 ani), usually as branches of secondary school lyceums.
} 
lyceum. The length of training varied by trade and depending on whether students completed an additional two years of general education: "In 1967-68 vocational schools offered training in 232 trades, 175 of which required 3 years and 57, 2 years." (Braham, 1972, p. 73)

Lyceums also operated at two distinct levels. The first level corresponded to grades 9 and 10 of compulsory general education, while the second level encompassed general education in grades 11 and 12. Curriculum in the first level was essentially homogenous across lyceums:

"During the first 2-years of lyceum education, students are offered a basically uniform curriculum both in academic and practical subjects whatever the character or orientation of a lyceum, its stated aims are to offer a well-balanced integrated curriculum composed of a number of subjects in the humanities, social studies, and the sciences, as well as subjects related to practical training in a particular field." (Braham, 1978, p. 10)

Graduates from the first level of lyceum who did not take further courses in the second level received a certificate of graduation from 10-year compulsory education (cerificat de absolvire a învătămîntului obligatoriu de 10 ani). Admission to the second level was based on a composite score computed from academic achievement in the lower level and a competitive entrance exam. Graduates from the second level who passed the baccalaureate exam received the baccalaureate diploma (diploma de bacalaureat) while those who failed received a certificate of graduation (certificat de absolvire). The vast majority of students enrolled in the second level of lyceum did pass the baccalaureate exam.

Entrance to higher education in universities, institutes, academies and conservatories was open to graduates of the second level of lyceum schools and required a baccalaureate diploma. ${ }^{10}$ Universities were under the central control and supervision of the Ministry of

\footnotetext{
${ }^{10}$ In addition, technical schools for master craftsmen admitted graduates of vocational schools who had spent between 3 and 5 years in production. A small number of postsecondary specialization schools admitted graduates of lyceums and trained them in specialized fields, but these were abolished in 1977.
} 
Education, which also determined the number of openings at the different universities in accordance with current and projected needs. During the 1960s, the number of university slots was expanded very rapidly with enrollment in 1968-69 more than double that in 1960-1961. (Braham, 1972) However, enrollment remained roughly constant throughout the 1970s. In 1975-1976, Romania had 42 institutions of higher education which offered degrees varying from a minimum of 3 years for teacher training to a maximum of 6 years for medicine. Admission to university was open to all graduates of secondary education holding a baccalaureate diploma and entry was based on a competitive oral and written exams administered in July of each year. Successful applicants were selected solely based on the scores achieved on these exams, subject to the predetermined quotas at each university. (Braham, p. 18) In contrast to the baccalaureate exam, university entrance exams were much harder to pass and it was not uncommon for a student to re-apply for a number of years before being admitted. Once accepted, students very rarely dropped out of university so attendance and graduation rates were very similar.

Thus, in most respects, the educational system in Romania was quite comparable to those which existed (and continue to exist) in many other countries. Schools followed a national curriculum and entry into high schools and universities was supply constrained with admission based on competitive exams. Although the Communist labor market of the 1970s was associated with a highly compressed wage structure, attending a prestigious lyceum or university was considered an extremely desirable outcome. Even under Communism, higher education bestowed social status and allowed entry into the more highly valued professional jobs. As a result, we believe that the findings of this study are largely applicable to other settings. 


\subsection{The Educational Reform of 1973}

The educational reforms of 1973, consisting of Decree No. 278 and the Resolution of the Communist Party's Central Committee of June 18 and 19, 1973, were intended to increase the proportion of students with 10 years of general schooling. In particular, the Resolution of June 1973 stated that "beginning with the school year 1974-75, the entire graduating class of grade 8 will start in grade 9 of lyceums; vocational schools will no longer accept students from this class [grade 8] directly." ${ }^{11}$ Thus, these reforms prevented students from entering vocational schools after 8 years of general education and required them to enter the first level of lyceum schools instead. The structures of the educational system before and after the change in 1973 are depicted in Appendix Figure 1. Depending on their aptitudes, skills, and preferences, graduates of the first level of lyceum schools could (i) enter the workforce, (ii) continue to vocational school for 1 year, or (iii) continue to grades 11 and 12 in the second level of lyceum schools. The emphasis on additional general education after 1973 caused a marked decrease in the prevalence of vocational training. As one secondary source explains, the number of students in vocational schools "decreased during the 1970's because of the extension of compulsory education to include 2 years in the lyceum." (Braham, 1978, p. 11)

The Resolution of June 1973 also introduced measures to assure that sufficient qualified teachers and school resources (such as science laboratories, classrooms, and dormitories) were allocated to local authorities. In most cases, these measures did not require any physical movement of resources; teachers and schools remained the same but their training and the

\footnotetext{
${ }^{11}$ These excerpts from the Resolution of the Communist Party's Central Committee of June 18 and 19, 1973 are translated by the authors from the original Romanian text.
} 
curriculum were changed. Specifically, the 1973 Resolution stated that:

"In order to provide for an effective educational environment and to use the existing facilities efficiently,...lyceums will, in general, function within the same premises as vocational schools and under the same leadership."

Since the cohort of students who were prevented from entering vocational schools after grade 8 in the fall of 1974 were usually placed in the first level of lyceum within existing vocational schools, these students remained within mostly similar peer groups before and after the policy change in grades 9 and 10. With some expansion of the second level of lyceums after the reform, we expect that the marginal student who entered this track was exposed to better peers, on average, during the final two years of secondary school. However, as seen in Appendix Figure 4, the largest increase in lyceum enrollment was in the somewhat lower ranked industrial high schools. Thus, while the marginal student who graduated from a lyceum rather than a vocational school due to the policy change was probably exposed to better peers, the increase in peer quality was likely limited because of the already high level of sorting in different types of lyceums prior to the policy change. ${ }^{12}$

We can document some of these changes using the Annual Statistics of the Socialist Republic of Romanian. Appendix Figure 2 shows the large decline in the number of students enrolled in vocational schools and on-the-job apprenticeships between the school years 197374 and 1975-76. During this period, enrollment in lyceums increased sharply, as shown in Appendix Figure 3. At the same time, the number of teachers in vocational schools fell and the number of teachers in lyceums rose in the initial years following the educational reform.

\footnotetext{
${ }^{12}$ The effect of changing peer groups on educational attainment and other outcome would be essentially zero in the presence of linear peer effects. However, since we are interested in the participation rates of different groups in higher education, any changes in peer groups may be an important factor in explaining our results.
} 
Further evidence for these dramatic changes is available from the Romanian Census of 1992. Since students began their compulsory schooling at age 6 , they would have completed grade 8 by age 14 and grade 10 by age 16 . As a result, students born in 1958 would have been unaffected by the policy while those students born in 1959 would have been required to continue to grades 9 and 10 of lyceum schools. Figure 1 shows the highest educational attainment by year of birth for individuals from the Romanian Census of 1992. There is a sharp decline in the proportion of individuals with vocational training between cohorts born in 1958 and 1959. At the same time, we observe a sharp increase in the proportion of individuals who completed the general lyceum education. In particular, we see a very large increase in the proportion of students who complete the second stage of lyceum education. No such discontinuity is observed for the proportion completing only lower/primary or those completing university. This is consistent with the historical evidence that the supply of slots at Romanian universities did not change for the cohorts affected by the 1973 educational reform.

\section{Empirical Strategy}

\subsection{Data}

The primary dataset for the empirical analysis combines two independent random samples from the 1992 Romanian Census. ${ }^{13}$ For each respondent, the census collected basic socioeconomic characteristics (such as gender, ethnicity, region of birth, rural/urban indicator of

\footnotetext{
${ }^{13}$ These include a $15 \%$ sample provided by the Population Activities Unit (PAU) of the United Nations Economic Commission for Europe (UNECE) and a 10\% sample recently released by IPUMS International. We have verified that these two samples are two separate random draws from the universe of all responses.
} 
birth) and detailed information about the highest level of educational attainment. Education levels are classified as follows: primary education, gymnasium education, first stage of lyceum education (grade 9 and 10), second stage of lyceum education (grades 11 and 12), vocational training and apprenticeships, post-secondary education, and university education. ${ }^{14}$ Two features make this dataset especially useful for our analysis: First, with approximately 90,000 observations in each yearly birth cohort, we have sufficient power to employ a regression discontinuity design. Second, there is detailed information about the month and year of birth so we can identify the discontinuity induced by the policy within a narrow window of time.

A number of the individual and parental background indicators serve as important markers of social class. Among these, whether an individual was born in a rural or urban setting is a particularly relevant indicator in Romania, whose economy prior to World War II was primarily oriented towards agriculture. ${ }^{15}$ We also define a dummy variable indicating whether an individual was born in one of the 20 (out of 41) poorest regions of the country, as measured by regional GDP in the 1990's. Moreover, we interact the two preceding variables to construct an indicator of being born in a rural locality of a poor region. To examine parental characteristics, we have to restrict our attention to those individuals who are still in the same household as their parents. Although this sample is not completely representative of the overall population, we have tested that the probability of living with a parent is not affected by the educational reform (not shown here). We consider indicators for whether

\footnotetext{
${ }^{14}$ Note that, since these categories are mutually exclusive, we cannot determine whether students with vocational training and apprenticeships also completed the first stage of lyceum education.

${ }^{15}$ Rural poverty has continued to be an important social problem in Romania during the transition period. (Florian and Serbanescu, 1998)
} 
each of the parents has only a primary education or less.

Table 1 presents summary statistics for the main variables used in the study. For cohorts born between 1957 and 1961: some 27 percent complete vocational training, 4 percent finish only the first stage of academic high-school, and 27 percent complete all four years of academic high school. Over 9 percent of students graduate from university while only 1 percent of students complete some other form of post-secondary training. Summing the last three categories, we can determine that almost 38 percent of students were eligible by law to apply for entrance at one of the state universities (including, of course, those who actually completed university). Roughly 72 percent of the students are rural born, indicating that Romania was a predominantly rural country even through the late 1950s. Finally, parental educational is very low, with 50 percent of fathers and 64 percent of mothers having received only a primary education or no education at all.

\subsection{A Regression Discontinuity Design}

In order to estimate the effect of postponing tracking, we take advantage of the 1973 educational reform which prevented students from entering vocational schools with only 8 years of schooling and, instead, required them to receive an additional two years of general education. Since this reform took effect during the 1974-75 school year and students entered grade 1 in September after the calendar year in which they reached 6 years of age, those individuals born before January 1, 1959 were unaffected by the policy while those born after this date

had their tracking postponed. With detailed information on date of birth, we can estimate the impact of this policy using a regression discontinuity design. 
We first examine the effect of the 1973 educational reform on educational attainment. Our primary educational outcomes include (i) eligibility to apply to university and (ii) university graduation. We consider the following regression equation:

$$
\text { educational_outcome } e_{i}=\beta^{\prime} \mathbf{X}_{i}+\alpha A F T E R_{i}+f\left(c_{i}\right)+\varepsilon_{i}
$$

where $\mathbf{X}_{i}$ includes fixed effects for calender month of birth to control for seasonal differences between individuals born in different months. AFTER $R_{i}$ is equal to 1 if individual $i$ was born on or after January 1, 1959 and 0 if born on or before December 31, 1958. Finally, $f\left(c_{i}\right)$ is a function of date of birth, which is the forcing variable in this context. As in many recent studies employing this technique and as suggested by Imbens and Lemieux (2008), we specify a flexible parametric model by including higher order polynomials of date of birth which are allowed to vary on either side of the discontinuity. ${ }^{16}$ We consider specifications that use linear, quadratic and cubic trends in month of birth, as well as linear, quadratic, and cubic splines (i.e. trends where the month of birth is fully interacted with $A F T E R) .{ }^{17}$ All binary outcome variables are shown estimated with a linear probability model but we also verify that non-linear regression methods, such as logit and probit, yield similar results.

Next, we examine how the 1973 educational reform changed the composition of students from certain social classes who were eligible to apply to university or who graduated from

\footnotetext{
${ }^{16}$ See Dinardo and Lee (2004) for use of parametric functions in regression discontinuity design. Lee and McCrary (2005) and Card, Dobkin, and Maestas (2004) specifically use parametric functions of date of birth.

${ }^{17}$ Estimating this equation using non-parametric methods, along the lines of Hahn, Todd, and van der Klaauw (2001) and Porter (2003), also leads to similar results.
} 
university. To answer this question, we consider the following regression model:

$$
\text { social_class }_{i}=\lambda^{\prime} \mathbf{X}_{i}+\delta A F T E R_{i}+f\left(c_{i}\right)+v_{i}
$$

where all of the right-hand side variables are defined as in equation 1, and social_class $s_{i}$ is one of our five markers of social class based personal and parental background characteristics: (i) rural/urban place of birth, (ii) born in poor region, (iii) born in poor region in rural locality, (iv) mother has only primary education or less and (v) father has only primary education or less. We run this regression for the sample of students who are eligible for university and for the sample who complete university. Consequently, in this specification, the coefficient on $A F T E R_{i}$ indicates the effect of the reform on the proportion of disadvantaged students eligible for or graduating from university.

Our regression-discontinuity (RD) approach essentially compares the outcomes of individuals in cohorts affected by the 1973 educational reform to their counterparts in cohorts born too early to be affected. We use a three year window on either side of the cutoff, including all individual born between January of 1957 and December 1961. The choice of the window is somewhat arbitrary as we need to strike a balance between the advantages of having more precise estimates when using larger windows with possible confounding time effects that are mitigated when a more narrow window is used. Therefore, we also present robustness checks where we rerun our main specifications with both broader and narrower windows. 


\section{Results}

\subsection{Effect of the reform on educational attainment}

The 1973 reform had a dramatic effect on the level and type of educational attainment, shown in Figure 1. As mentioned previously, the reform forced students to enter vocational school after 10 years of schooling and therefore required them to receive an additional 2 years of general education. Moreover, the reform also increased the number of slots in academic high schools for the remaining two years (in grades 11 and 12). Table 2 provides precise estimates for the impact of the reform on several different educational outcomes, corresponding to equation 1 from the preceding section. The rows show the coefficient on AFTER using alternative polynomial trends. Column (1) shows that children born after January 1959 were between 7 and 10 percentage points less likely to receive a vocational education. Given that the base probability of receiving a vocational education during this period was about 0.27, this represents an extremely large effect. Columns (2) and (3) reveal that students who were shifted out of vocational schools ended up completing their education in academic schools instead. The larger increase was among students who attained the full four years of general high school education, and thereby became eligible to apply for university. On the other hand, columns (4) and (5) indicate that the 1973 reform had only a small effect on post-secondary educational attainment and virtually no effect on university graduation. ${ }^{18}$ Eligibility for university includes students who completed the full four years of general lyceum education, as well as those who actually went on to complete a post-secondary or university

\footnotetext{
${ }^{18}$ Figure 1 makes clear that the importance of post-secondary education is relatively small and diminshed even further after the reform. Moreover, the coefficient on AFTER in column (4) is only significant in certain specifications.
} 
education. Column (6) shows that the 1973 reform increased eligibility for university by approximately 5 percentage points, or over 13 percent, regardless of which polynomial trend is used to control for the forcing variable.

These results are consistent with our understanding of the educational system in Romania and the specific reform of 1973: The policy change switched a large fraction of students from vocational to academic high schools. As a result, many more students were able to take the baccalaureate exam at the end of high school and become eligible to take the entrance exam at one of the nation's state universities. However, this did not translate into an increase in overall university graduation because the number of university slots were constrained by the government and remained unchanged during our period of study. Figure 2 plots the proportion of individuals eligible for university and the proportion of individuals graduating from university by month and week of birth. As expected, Panels A and C show an extremely sharp discontinuity after January, 1959 (normalized as month 0) for those eligible for university. Individuals born merely two weeks apart had very different likelihoods of being eligible for university. No such discontinuity can be observed for the fraction of students completing university in Panels B and D.

\subsection{Effect of the reform on access to higher education}

Having established that the 1973 educational reform increased the overall fraction of students

eligible to apply to university, we consider the impact of the reform on the social composition of students eligible to apply for university. Table 3 presents regression results for the sample of students eligible to apply for university, corresponding to equation 2 from the previous 
section. Column (1) indicates that the 1973 educational reform increased the proportion of eligible students who were born in a rural region by approximately 4 percentage points, using any number of different polynomial trends. Similarly, column (2) shows that the proportion of eligible students who were born in a poor region increased by over 2 percentage points. Combining these two dependent variables, column (3) reveals that the proportion of eligible students who were born in poor and rural regions increased by almost 10 percent. The effect of the policy on social composition in terms of parental education is even more striking. ${ }^{19}$ Columns (4) and (5) display the effect on the proportion of eligible students whose mother or father had a minimal level of educational attainment. In either case, the estimated impact of the educational reform on the proportion of individuals with less educated parents is large and highly significant. Figure 3 also reveals a sharp discontinuous jump in the proportion of eligible students who come from poor and disadvantaged backgrounds according to all five markers of social class. ${ }^{20}$ We interpret these results as evidence that the marginal person affected by the reform came from a lower social class than the average person who was eligible to apply for university. In other words, the reform increased the likelihood that children from less advantaged backgrounds would complete an academic high school and have the opportunity to apply for university.

We proceed to examine whether the increase in eligibility for university among disadvantaged students was also associated with an increase in the probability of graduating from

\footnotetext{
${ }^{19}$ As mentioned earlier, the sample of individuals still living with their parents is not necessarily representative of the overall population. However, the probability of living with one's parents does not reveal a discontinuity around the birth cohort cutoff suggesting this is not a concern given our design.

${ }^{20}$ The open circles plot residuals from regressions of the dependent variables on fixed effects for calendar month of birth, to eliminate seasonal differences. The solid lines are fitted values to residuals from regressions of the dependent variable on a quadratic polynomial in month of birth.
} 
university. Figure 4 displays the proportion of university graduates who were born in rural regions, poor regions, rural and poor regions, as well as those whose mother or father have especially low levels of educational attainment. This graph is analogous to Figure 3 but with the sample restricted to students who graduated from university. In contrast to the patterns for eligibility, we do not observe any discontinuities in the composition of social class for university graduation. These findings are confirmed in Table 4 which shows that the estimated coefficients on $A F T E R_{i}$ are essentially zero for almost all the alternative polynomial trends. The effects are somewhat less precisely estimated in the case of parental education due to sample size and with the inclusion of some higher order polynomial trends. Nevertheless, the pattern is consistent across all markers of social class. The 1973 educational reform made students from disadvantaged background relatively more likely to be eligible for university but this did not translate into a increase in the proportion of disadvantaged students completing university.

\subsection{Robustness checks}

We have performed a number of additional tests to check the robustness of our results. Appendix Table 1 focuses on the effect of the educational reform on eligibility for university. In Panel A, we consider three alternative windows around the discontinuity: a one year window including students born between 1958 and 1959, a two year window including students born between 1957 and 1960, and a four year window including students born between

1955 and 1962. As in Table 3, the effect of the 1973 educational reform on the proportion of eligible students from disadvantaged backgrounds is highly significant in each of these 
specifications. Panel B presents estimates for the effect around alternative year cutoffs. In essence, we consider "placebo experiments" around January 1 of the two preceding years and two following years. We find no significant difference in proportion of eligible students from disadvantaged backgrounds using these alternative year cutoffs around January 1 of 1957, 1958, 1960 and 1961. ${ }^{21}$ Appendix Table 2 focuses on the effect of the educational reform on university graduation. Panel A indicates that there are no significant differences in the proportion of university graduates from disadvantaged backgrounds using either broader or narrower windows around the discontinuity. Panel B shows that there is no significant difference in the proportion of university graduates from disadvantaged backgrounds using alternative year cutoffs.

\subsection{Quality of education}

As noted earlier, the competitive nature of entry into secondary education resulted in substantial sorting of students by socio-economic background. Hence, even before the educational reform, it is likely that students from disadvantaged backgrounds were enrolled in schools with less able peers. These schools may have also drawn teachers from lower parts of the ability distribution. Though the reform would have increased the average quality of peers for the marginal student affected, the evidence suggests that most of the affected students attended the less prestigious industrial high schools. Therefore, the postponement of tracking probably did not drastically increase the quality of peers or schools for these disadvantaged students but, rather, opened up the opportunity to complete an academic

\footnotetext{
${ }^{21}$ The only year with consistently significant results is for the eligibility regressions using the 1961 cut-off. However, the sign of the effect goes in the opposite direction.
} 
track in high school and apply to university.

The drastic expansion of general education in Romania so essential to credibly identifying the effect of vocational training may have also caused a short-run reduction in the quality of academic education. Moreover, with an educational reform that affected such a large fraction of the school-age population, the question of how resources were allocated to implement the reform becomes extremely important. As mentioned previously, the 1973 educational reform involved the reorganization of existing vocational schools which were transformed into "combo schools" offering both vocational and general high school education. Appendix Figures 2 and 3 show the influx of teachers from vocational to general high school and indicate that the average student/faculty ratios across the two types of schools were largely maintained. Although we have some anecdotal evidence that retraining occurred, these teachers may nevertheless have been relatively inexperienced at teaching the new curriculum. Nevertheless, in a related paper, we provide evidence that changes in the quality of academic schools were unlikely to explain the absence of effects on labor market outcomes in later years. (Malamud and Pop-Eleches, 2006)

\section{Conclusion}

Whether the relationship between family background and access to higher education can be influenced by the timing of educational transitions in secondary school is an important question for human capital policy. This paper examines an educational reform in Romania which postponed the timing of tracking into academic and vocational schools. As a result, the proportion of students who became eligible to apply to university increased sharply, even 
while the number of university slots remained unchanged. Using data from the Romanian Census, we show that students from poor, rural areas and from less educated families who were less likely to complete university, were those most affected most by the policy. However, although these disadvantaged students were significantly more likely to become eligible to apply for university after the reform, we find no corresponding increase in their relative likelihood of completing university. ${ }^{22}$ In other words, the postponement of tracking did not seem to help disadvantaged students catch with their more privileged counterparts.

How do we interpret these findings? If more time in academic schools had enabled disadvantaged students to catch up with their privileged counterparts, postponing the timing of selection should have increased university completion among the disadvantaged. Instead, our findings suggest that simply postponing tracking, without increasing the number of slots available in university, was not sufficient to improve access to higher education. It is plausible that simply providing disadvantaged students with the opportunity to apply to university could have had an effect on university completion. That we do not find any effect is striking evidence to the contrary.

\footnotetext{
${ }^{22}$ These findings also serve to reinforce the interpretation offered in Malamud and Pop-Eleches (2006) where we focus on the labor market effects that resulted from the increased exposure to general education rather than vocational training.
} 


\section{References}

Aakvik, A., Salvanes, K. G., and K. Vaage (2003) "Measuring heterogeneity in the returns to schooling in Norway using educational reforms" Centre for Economic Policy Research, Discussion paper No. 4088

Blindeanu, E. (1972) Invatamintul Secundar de Cultura Generala Din Diferite Tari, Editura Didactica si Pedagogica Bucuresti

Braham, R.L. (1972) Education in Romania: A Decade of Change, US Government Printing Press

Braham, R.L. (1978) The Educational System of Romania, US Government Printing Press

Brunello, G., K,Ariga and M.Giannini. (2006) The Optimal Timing of School Tracking, in Schools and the Equal Opportunity Problem (eds P. Peterson and L.Wößmann). MIT Press: Cambridge MA

Carniero, P. and J. Heckman (2002) "The Evidence on Credit Constraints in PostSecondary Schooling" Economic Journal 112: 705-734

Dimitriu, E., Ionescu, O. Nica, I. and I. Orghidan (1981) A Concise History of Education in Romania, Editura Stiintifica si Enciclopedica

Duflo, E., P. Dupas, M. Kremer (2007) "Peer Effects, Pupil-Teacher Ratios, and Teacher Incentives: Evidence from a Randomized Evaluation in Kenya," Harvard University mimeo

Dustmann, C. (2004) "Parental background, secondary school track choice, and wages" Oxford Economic Papers 56: 209-230

Ellwood, D.T. and T.J. Kane (2000) "Who is Getting a College Education? Family Background and the Growing Gaps in Education," in Securing the Future: Investing in Children from Birth to College, (eds. S. Danziger and J. Waldfogel), New York: Ford Foundation Series on Asset Building

Florian V. and C. Serbanescu C. (1998) "Food consumption and rural poverty in Romania during transition to market" . In Mergos G. (ed.) . Agricultural price reform under transition in Bulgaria, Romania, and Slovenia Chania: CIHEAM-IAMC, 223-232

Hahn, J., Todd, P., and W. van der Klaauw (2001) "Identification and Estimation of Treatment Effects with a Regression Discontinuity Design" Econometrica 69(1): 201-209

Hanushek, E. and L. Wößmann (2006) "Does Educational Tracking affect Performance and Inequality? Differences-in-Differences Evidence Across Countries" Economic Journal 116: $63-76$

Heckman, J.J. (2000) "Policies to Foster Human Capital" Research in Economics, 54(1), 3-56 
Heckman, J.J. and A. Krueger (2004) Inequality in America: What Role for Human Capital Policies? Cambridge, MA: MIT Press

Imbens, G.W. and T. Lemieux (2008) "Regression discontinuity designs: A guide to practice" Journal of Econometrics 127(2), 615-635

Leschinsky, A. and K.U. Mayer (1990) The Comprehensive School Experiment Revisited: Evidence from Western Europe Frankfurt am Main: Verlag Peter Lang

Malamud O. and C. Pop-Eleches (2006) "General Education vs. Vocational Training: Evidence from an Economy in Transition" mimeo

Manning, A. and J.S.Pisckhe (2006) "Comprehensive versus Selective Schooling in England in Wales: What Do We Know?" IZA Discussion Paper No. 2072

Mare, R.D. (1980) "Social Background and School Continuation Decisions" Journal of the American Statistical Association 75: 295-305

Maurin E. and S. McNally (2007) "Educational Effects of Widening Access to the Academic Track: A Natural Experiment" IZA Discussion Paper No. 2596

Meghir, C. and M. Palme (2005) "Educational Reform, Ability and Parental Background" American Economic Review, 95(1): 414-424

Muller, W., and W. Karle (1993) "Social Selection in Educational Systems in Europe." European Sociological Review 9: 1-23

Romanian Government (1968) The Education Law of the Socialist Republic of Romania, Didactical and Pedagogical Publishing House, Bucharest

Romanian Government (1973) Resolution of the Communist Party's Central Committee of June 18 and 19, 1973, Editura Politica, Bucharest

Romanian Government (1977) Presidential Decree Nr 191/1977 Article 25, Offiical Bulletin Nr. 67, Bucharest

Romanian Government, Annual Statistics of the Socialist Republic of Romanian 1960-1980

Shavit, Y., and H. Blossfeld (1993) Persistent Inequality: Changing Educational Attainment in Thirteen Countries. Boulder, Colo.: Westview Press 
Figure 1: Educational attainment for all individuals by birth cohort (Census 1992)

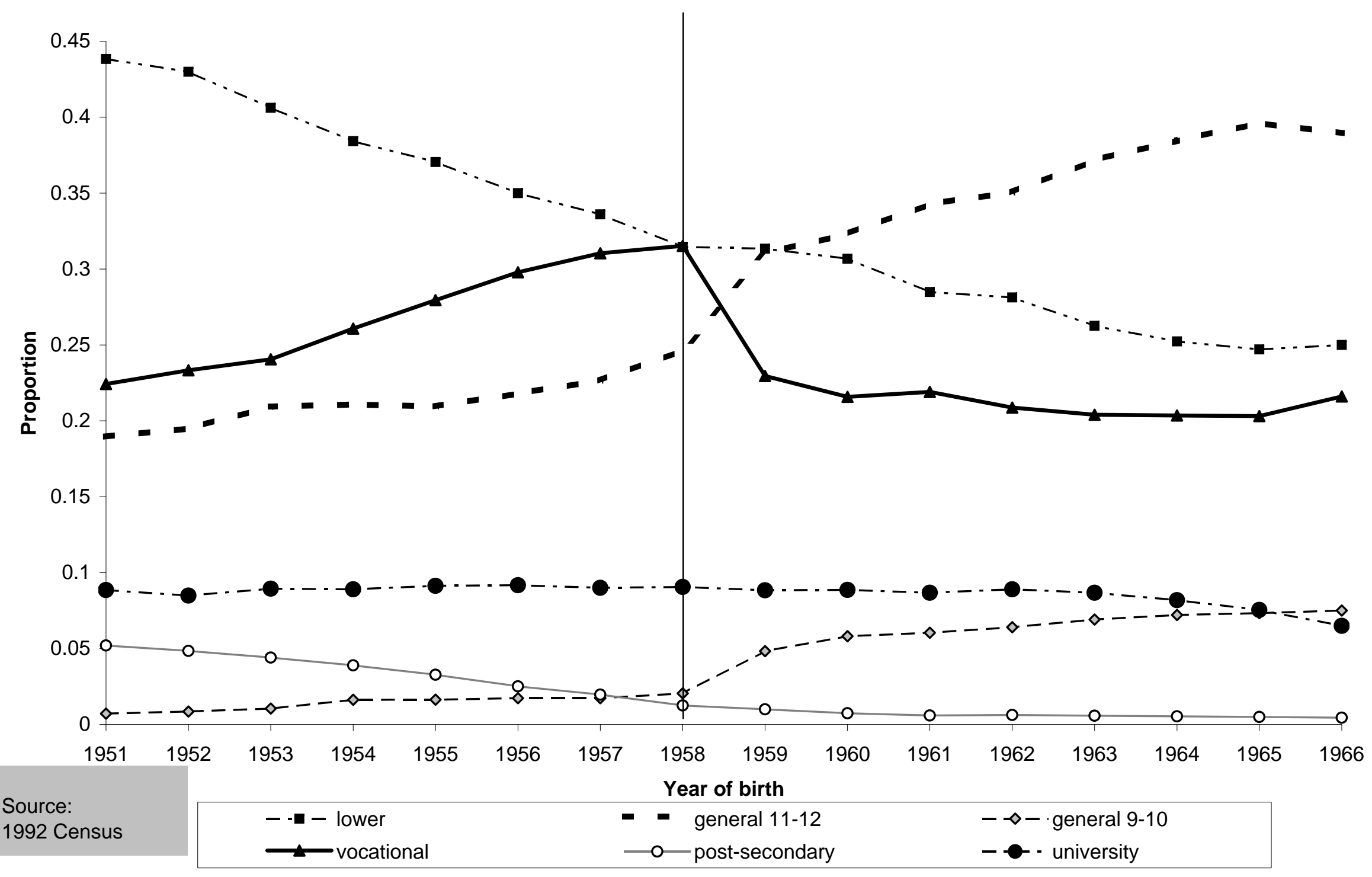


Figure 2: Proportion Eligible and Graduating from University
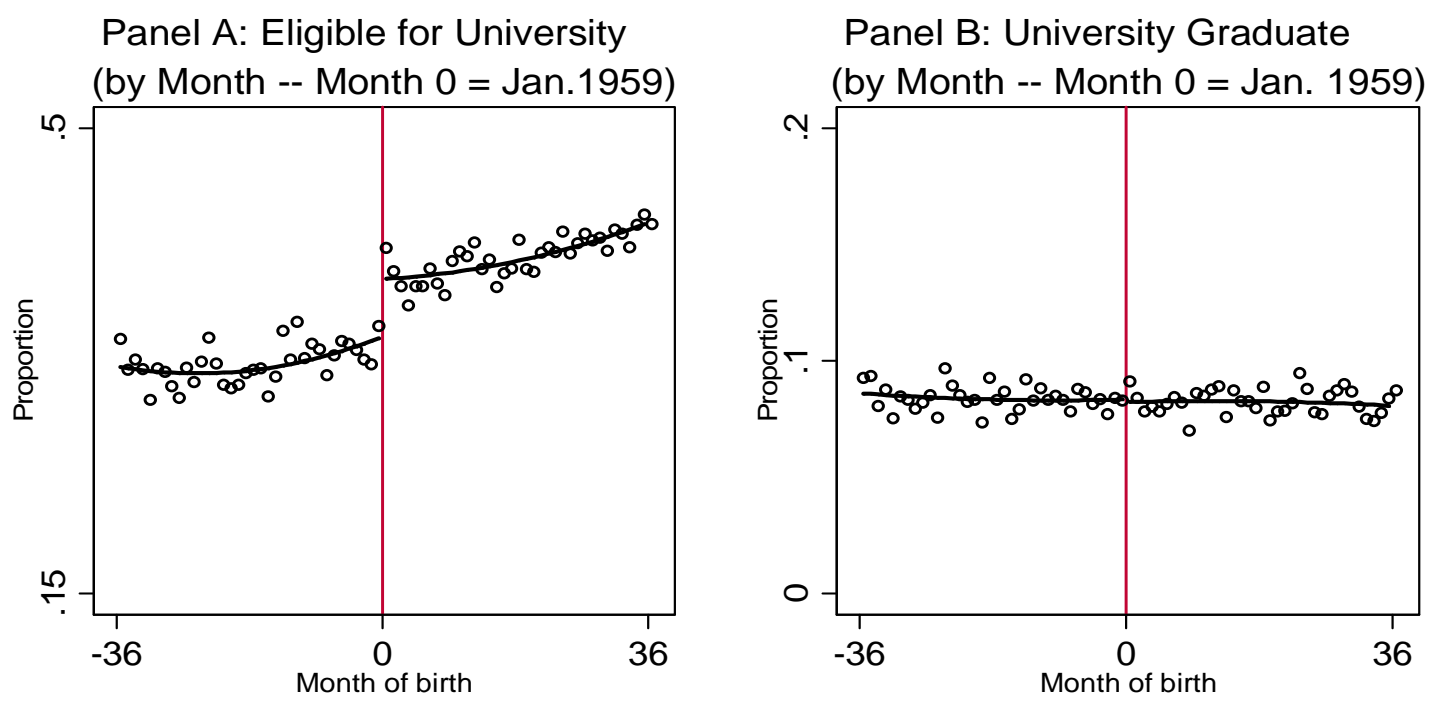

Panel C: Eligible for University (by Week -- Week 0 = Jan.1-7.1959)

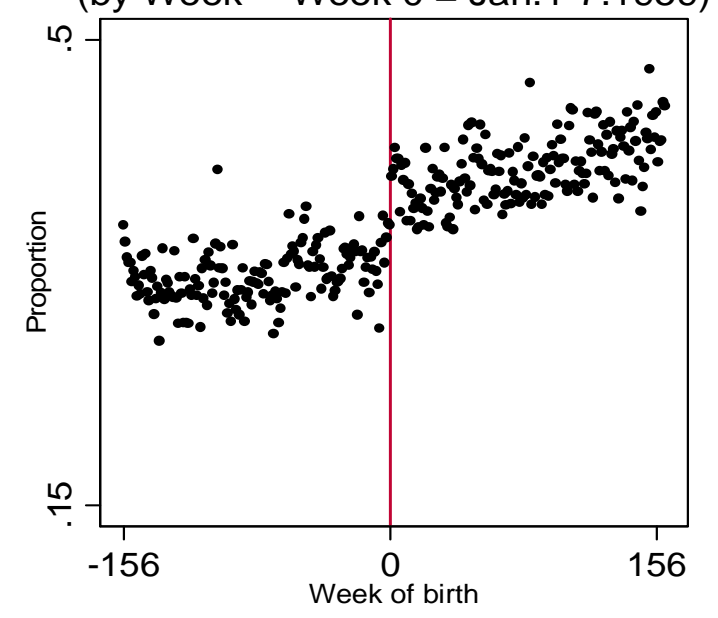

Panel D: University Graduate

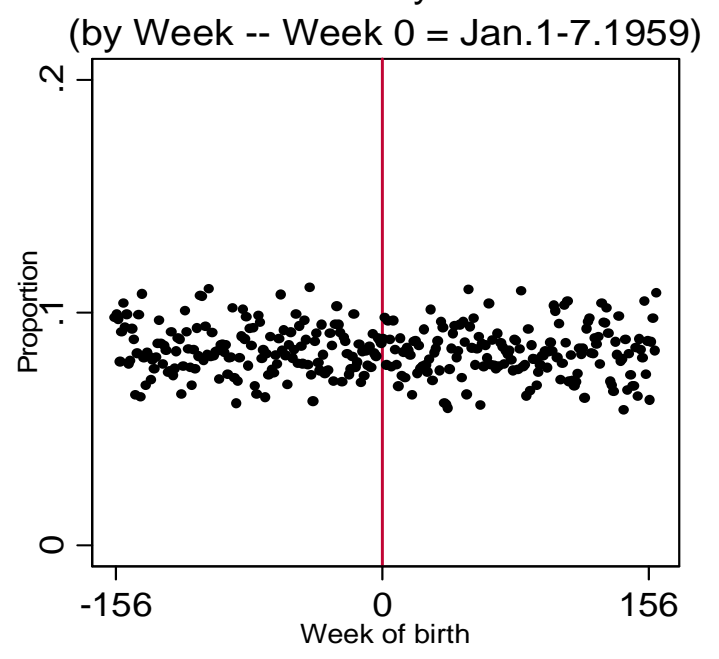

Notes: All panels are restricted to individuals born between January 1, 1956 and December 31, 1961. Panels A and C measure the proportion of individuals who were eligible to apply for university. Panels B and D measure the proportion of university graduates. Source: 1992 Romanian Census (PAU Sample). 
Figure 3: Eligibility to Apply to University (by Month of Birth)
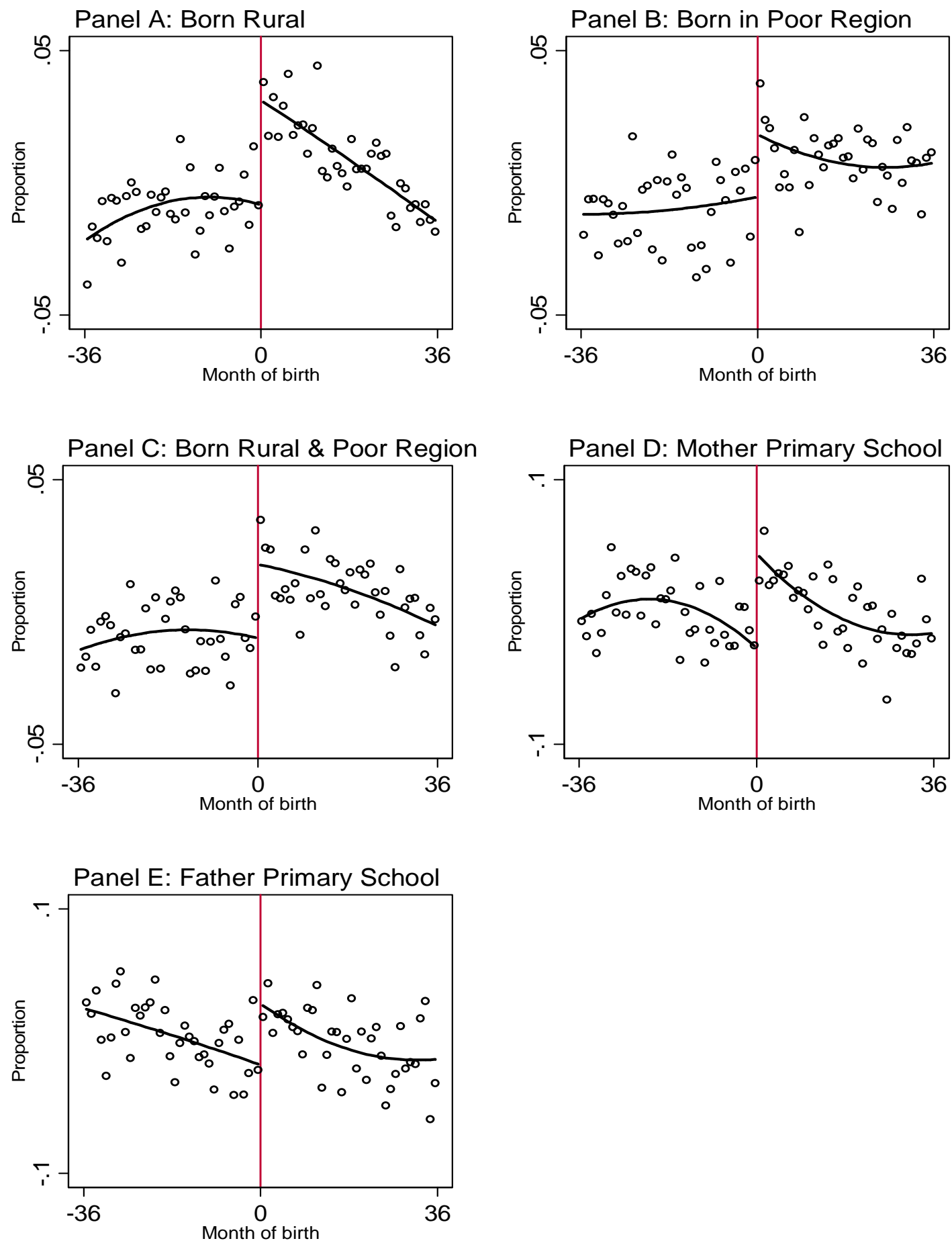

Notes: All panels are restricted to individuals born between January 1, 1956 and December 31, 1961 who were eligible to appply for university. The open circles plot residuals from regressions of the dependent variables on fixed effects for calendar month of birth. The solid lines are fitted values to residuals from regressions of the dependent variable on a quadratic polynomial in month of birth. Source: 1992 Romanian Census. 
Figure 4: Actual Graduation from University (by Month of Birth)
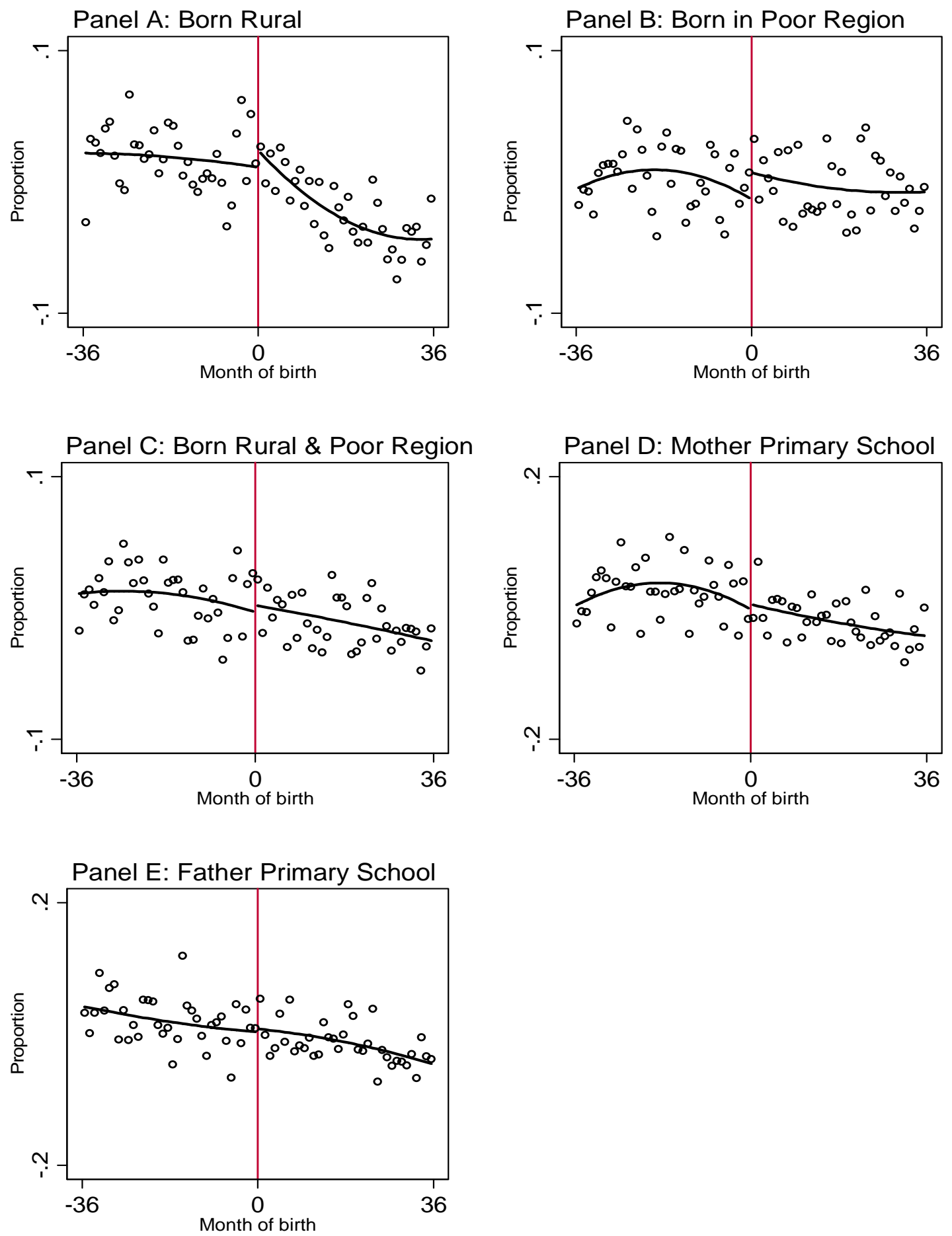

Notes: All panels are restricted to individuals born between January 1, 1956 and December 31, 1961 who graduated from university. The open circles plot residuals from regressions of the dependent variables on fixed effects for calendar month of birth. The solid lines are fitted values to residuals from regressions of the dependent variable on a quadratic polynomial in month of birth. Source: 1992 Romanian Census. 


\title{
Appendix Figure 1: Structure of Education in Romaina
}

\author{
Panel A: Before 1973
}

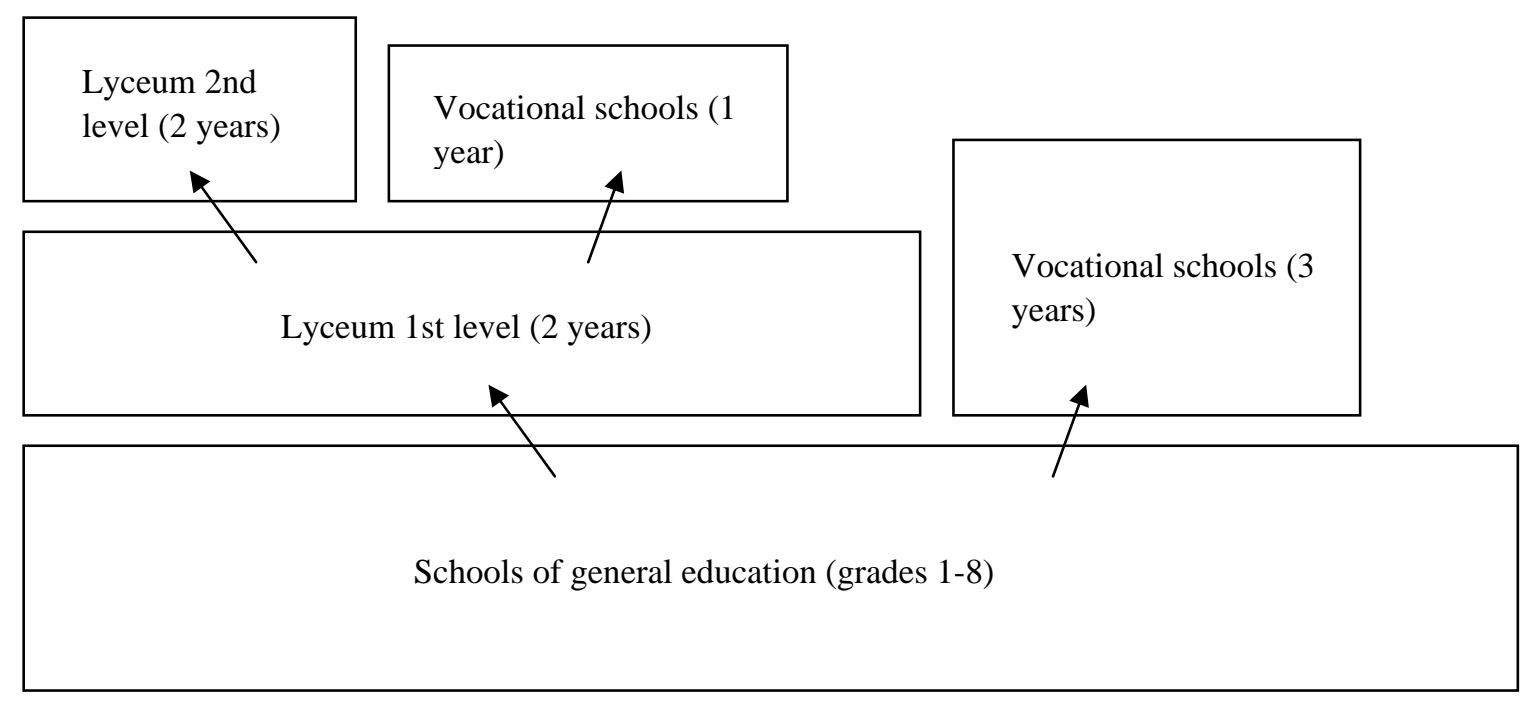

Panel B: After 1973

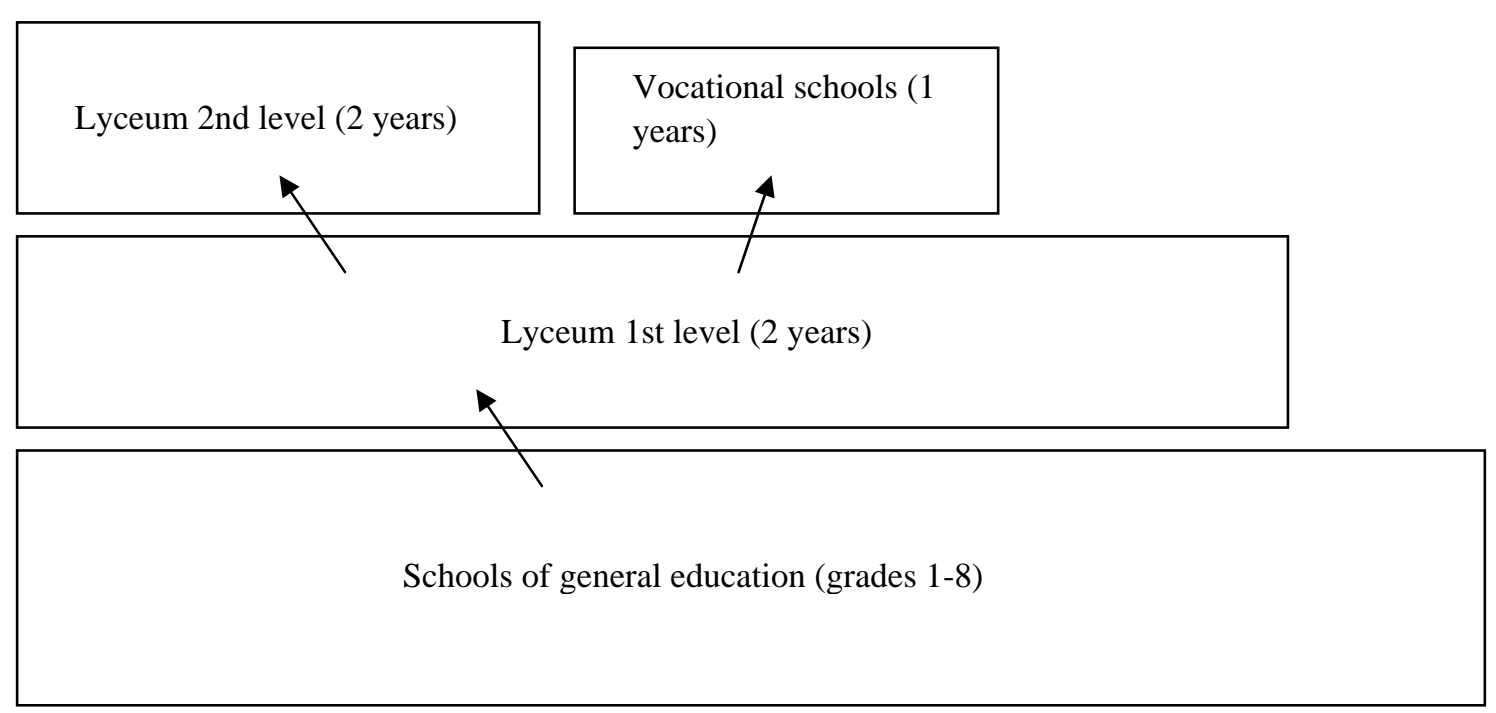




\section{Appendix Figure 2: Enrollment in Vocational schools and}

\section{Apprenticeships by school-year}

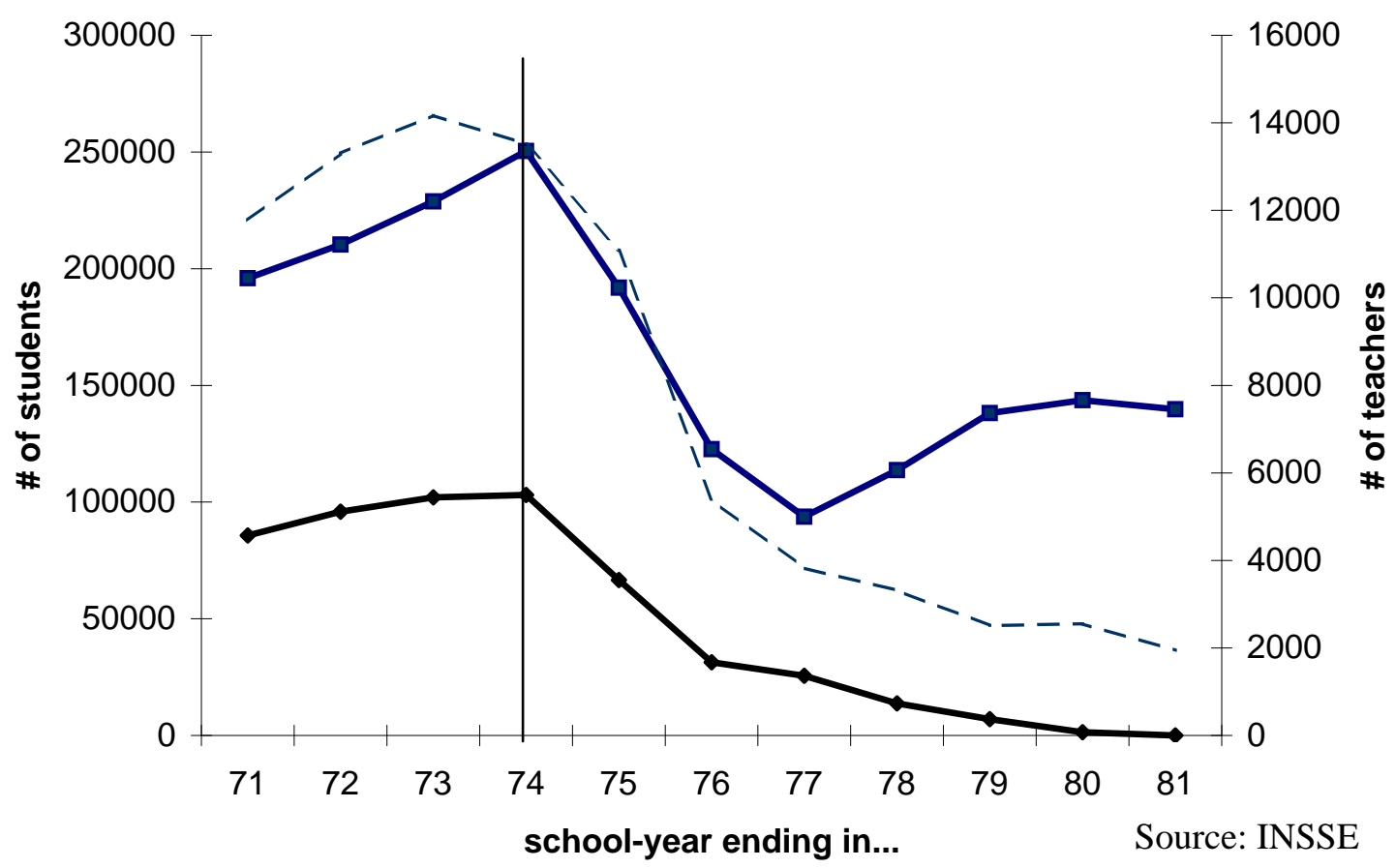

$\longrightarrow$ Vocational students $\longrightarrow$ Apprenticeships students --- Teachers

Appendix Figure 3: Enrollment in Lyceums by school-year

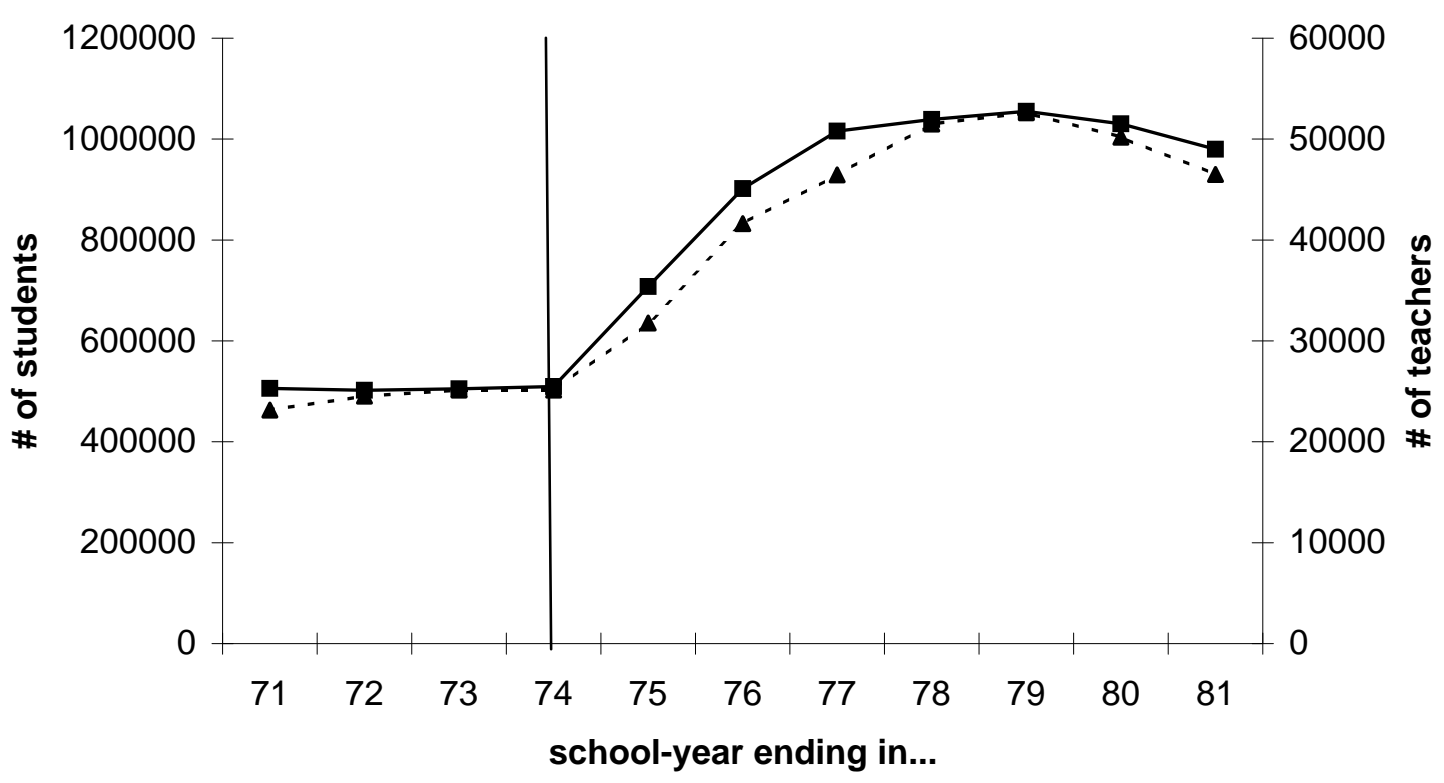

$\longrightarrow$ Lyceum students - - - - Teachers 


\section{Appendix Figure 4: Change in lyceum enrollment by main specialty}

from 1973-74 to 1976-77

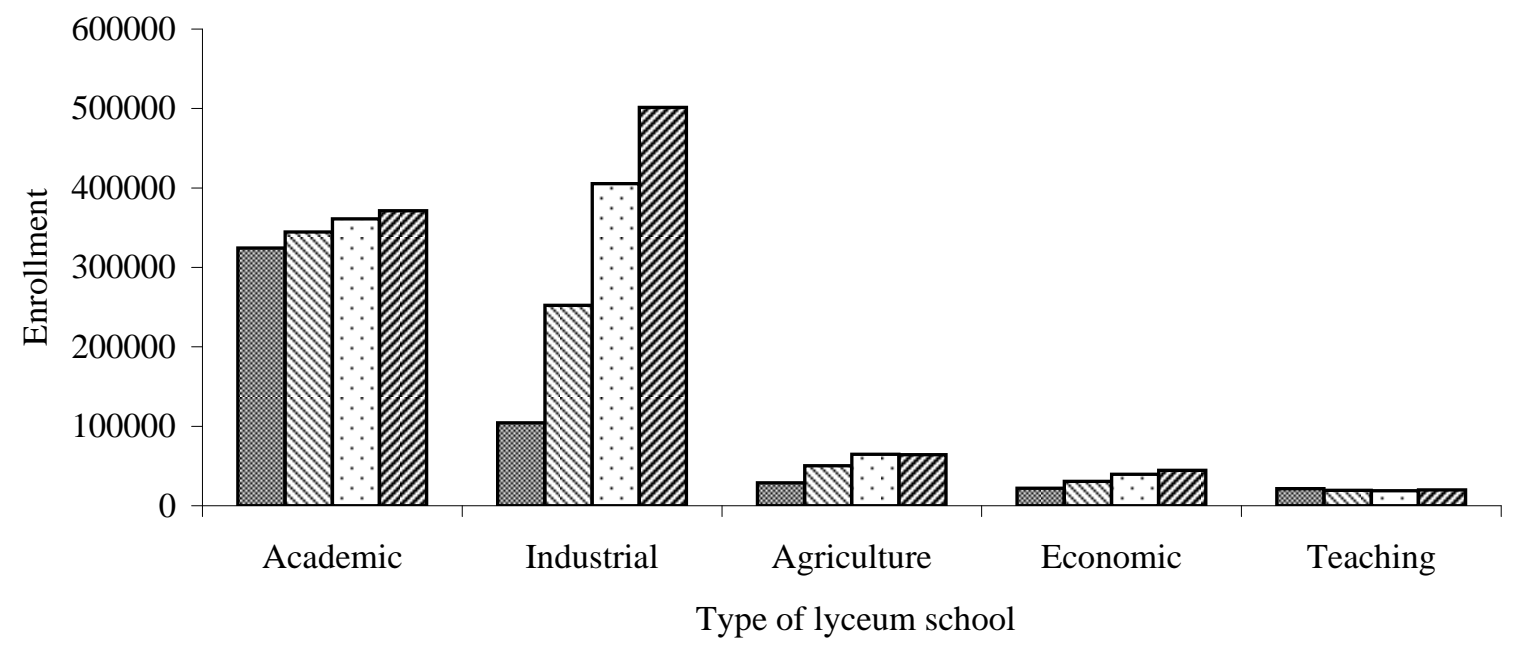

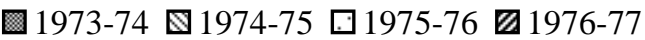

Source: INSSE 
Table 1: Descriptive Statistics

\begin{tabular}{lccc}
\hline \hline & \multicolumn{3}{c}{ Entire sample } \\
\cline { 2 - 4 } & Mean & SD & $\mathrm{N}$ \\
\cline { 2 - 4 } & & & \\
\cline { 2 - 4 } Educational Attainment & & & \\
Vocational & 0.27 & 0.45 & 448636 \\
General 9-10 & 0.04 & 0.19 & 448636 \\
General 11-12 & 0.27 & 0.44 & 448636 \\
Post secondary & 0.01 & 0.12 & 448636 \\
Eligible for University & 0.38 & 0.48 & 448636 \\
University Graduate & 0.09 & 0.28 & 448636 \\
& & & \\
Background Characteristics & & & \\
& & & \\
Rural Born & 0.72 & 0.45 & 449991 \\
Born Poor Region & 0.51 & 0.50 & 450156 \\
Born Rural and Poor Region & 0.40 & 0.49 & 449991 \\
Mother Primary Education & 0.64 & 0.48 & 86928 \\
Father Primary Education & 0.50 & 0.50 & 65447 \\
& & & \\
\hline \hline
\end{tabular}

Notes: SD is the standard deviation and $\mathrm{N}$ is the sample size. All summary statistics based on all individuals born between 1956 and 1961 (within 3 years of January 1, 1959). Source: 1992 Romanian Census. 
Table 2: The effect of the 1973 educational reform on educational outcomes (coefficients on AFTER)

\begin{tabular}{|c|c|c|c|c|c|c|}
\hline \multirow{3}{*}{ dependent variables: } & & & & & & \\
\hline & Vocational & General 9-10 & General 11-12 & Post Secondary & $\begin{array}{c}\text { University } \\
\text { Graduate }\end{array}$ & \multirow{2}{*}{$\begin{array}{c}\text { Eligible for } \\
\text { University } \\
\text { (6) }\end{array}$} \\
\hline & (1) & (2) & (3) & (4) & (5) & \\
\hline \multirow{2}{*}{ Linear trend } & $-0.093 * * *$ & $0.026 * * *$ & $0.050 * * *$ & 0.001 & -0.001 & $0.051^{* * *}$ \\
\hline & {$[0.005]$} & {$[0.002]$} & {$[0.003]$} & {$[0.001]$} & {$[0.001]$} & {$[0.003]$} \\
\hline \multirow{2}{*}{ Quadratic trend } & $-0.092 * * *$ & $0.026 * * *$ & $0.049 * * *$ & $0.001^{*}$ & -0.001 & $0.050 * * *$ \\
\hline & {$[0.003]$} & {$[0.002]$} & {$[0.003]$} & {$[0.001]$} & {$[0.001]$} & [0.003] \\
\hline \multirow{2}{*}{ Cubic trend } & $-0.080 * * *$ & $0.020 * * *$ & $0.046 * * *$ & $0.002 * *$ & $-0.003^{*}$ & $0.045 * * *$ \\
\hline & {$[0.004]$} & {$[0.002]$} & {$[0.004]$} & {$[0.001]$} & {$[0.002]$} & {$[0.004]$} \\
\hline \multirow{2}{*}{ Linear spline } & $-0.092 * * *$ & $0.026 * * *$ & $0.050 * * *$ & $0.001 * *$ & -0.001 & $0.050 * * *$ \\
\hline & {$[0.003]$} & {$[0.002]$} & {$[0.003]$} & {$[0.001]$} & {$[0.001]$} & [0.003] \\
\hline \multirow{2}{*}{ Quadratic spline } & $-0.076 * * *$ & $0.018 * * *$ & $0.044 * * *$ & $0.002 * * *$ & $-0.004 *$ & $0.043^{* * *}$ \\
\hline & {$[0.004]$} & {$[0.002]$} & {$[0.004]$} & {$[0.001]$} & {$[0.002]$} & [0.005] \\
\hline \multirow{2}{*}{ Cubic spline } & $-0.067 * * *$ & $0.016 * * *$ & $0.047 * * *$ & $0.003^{* *}$ & -0.002 & $0.049 * * *$ \\
\hline & {$[0.006]$} & {$[0.002]$} & {$[0.007]$} & {$[0.001]$} & {$[0.003]$} & {$[0.007]$} \\
\hline Cal. month dummies & $\mathrm{Y}$ & $\mathrm{Y}$ & $\mathrm{Y}$ & $\mathrm{Y}$ & $\mathrm{Y}$ & $\mathrm{Y}$ \\
\hline Sample Size & 448,636 & 448,636 & 448,636 & 448,636 & 448,636 & 448,636 \\
\hline Mean of dep. variable & 0.27 & 0.04 & 0.27 & 0.01 & 0.09 & 0.38 \\
\hline
\end{tabular}

Notes: Notes: Robust standard errors in brackets. ***, ** and * indicate statistical significance at the 1,5 and 10 percent level respectively. Samples include cohorts born between January 1, 1956 and December 31, 1961. AFTER is defined as 1 for individuals born on or after January 1, 1959 and 0 for individuals born on or before December 31, 1958. All regressions include 11 calendar month dummies. 
Table 3: Effect of the 1973 educational reform on eligibility for university (coefficients on AFTER)

\begin{tabular}{|c|c|c|c|c|c|}
\hline dependent variable & $\begin{array}{c}\text { Rural Born } \\
\text { (1) } \\
\end{array}$ & $\begin{array}{c}\text { Born Poor } \\
\text { Region } \\
(2) \\
\end{array}$ & $\begin{array}{c}\text { Born Rural and } \\
\text { Poor Region } \\
\text { (3) } \\
\end{array}$ & $\begin{array}{c}\text { Mother Primary } \\
\text { Education } \\
\text { (5) } \\
\end{array}$ & $\begin{array}{c}\text { Father Primary } \\
\text { Education } \\
\text { (6) }\end{array}$ \\
\hline Linear trend & $\begin{array}{c}0.038 * * * \\
{[0.007]}\end{array}$ & $\begin{array}{c}0.022^{* * *} \\
{[0.007]}\end{array}$ & $\begin{array}{c}0.028 * * * \\
{[0.006]}\end{array}$ & $\begin{array}{c}0.048 * * * \\
{[0.010]}\end{array}$ & $\begin{array}{c}0.040 * * * \\
{[0.009]}\end{array}$ \\
\hline Quadratic trend & $\begin{array}{c}0.037 * * * \\
{[0.005]}\end{array}$ & $\begin{array}{c}0.022^{* * *} \\
{[0.007]}\end{array}$ & $\begin{array}{c}0.028 * * * \\
{[0.006]}\end{array}$ & $\begin{array}{c}0.045^{* * *} \\
{[0.010]}\end{array}$ & $\begin{array}{c}0.040^{* * *} \\
{[0.009]}\end{array}$ \\
\hline Cubic trend & $\begin{array}{c}0.041^{* * *} \\
{[0.006]}\end{array}$ & $\begin{array}{c}0.024 * * * \\
{[0.009]}\end{array}$ & $\begin{array}{c}0.029 * * * \\
{[0.007]}\end{array}$ & $\begin{array}{c}0.070 * * * \\
{[0.011]}\end{array}$ & $\begin{array}{c}0.048 * * * \\
{[0.012]}\end{array}$ \\
\hline Linear spline & $\begin{array}{c}0.036^{* * *} \\
{[0.005]}\end{array}$ & $\begin{array}{c}0.021^{* * *} \\
{[0.007]}\end{array}$ & $\begin{array}{c}0.027^{* * *} \\
{[0.006]}\end{array}$ & $\begin{array}{c}0.045^{* * *} \\
{[0.009]}\end{array}$ & $\begin{array}{c}0.040^{* * *} \\
{[0.009]}\end{array}$ \\
\hline Quadratic spline & $\begin{array}{c}0.042^{* * *} \\
{[0.007]}\end{array}$ & $\begin{array}{c}0.024^{* *} \\
{[0.009]}\end{array}$ & $\begin{array}{c}0.030^{* * *} \\
{[0.008]}\end{array}$ & $\begin{array}{c}0.074^{* * *} \\
{[0.012]}\end{array}$ & $\begin{array}{c}0.049 * * * \\
{[0.014]}\end{array}$ \\
\hline Cubic spline & $\begin{array}{c}0.040^{* * *} \\
{[0.012]}\end{array}$ & $\begin{array}{c}0.024^{*} \\
{[0.012]}\end{array}$ & $\begin{array}{c}0.034^{* * *} \\
{[0.010]}\end{array}$ & $\begin{array}{c}0.046 * * \\
{[0.020]}\end{array}$ & $\begin{array}{c}0.049 * * \\
{[0.020]}\end{array}$ \\
\hline \multicolumn{6}{|l|}{ Cal. month dummies } \\
\hline & $\mathrm{Y}$ & $\mathrm{Y}$ & $\mathrm{Y}$ & $\mathrm{Y}$ & $\mathrm{Y}$ \\
\hline Sample Size & 170,857 & 170,970 & 170,857 & 31,962 & 24,822 \\
\hline Mean of dep. variable & 0.58 & 0.45 & 0.32 & 0.42 & 0.27 \\
\hline
\end{tabular}

Notes: Robust standard errors in brackets. ${ }^{* *}, * *$ and * indicate statistical significance at the 1,5 and 10 percent level respectively. Samples include cohorts born between January 1, 1956 and December 31, 1961 who achieved an educational attainment that allows them to apply for entrance at a university. AFTER is defined as 1 for individuals born on or after January 1, 1959 and 0 for individuals born on or before December 31, 1958. All regressions include 11 calendar month dummies. 
Table 4: Effect of the 1973 educational reform on university completion (coefficients on AFTER)

\begin{tabular}{|c|c|c|c|c|c|}
\hline dependent variable & $\begin{array}{c}\text { Rural Born } \\
\text { (1) }\end{array}$ & $\begin{array}{c}\text { Born Poor } \\
\text { Region } \\
\text { (2) }\end{array}$ & $\begin{array}{c}\text { Born Rural and } \\
\text { Poor Region } \\
\text { (3) }\end{array}$ & $\begin{array}{c}\text { Mother Primary } \\
\text { Education } \\
\text { (5) }\end{array}$ & $\begin{array}{c}\text { Father Primary } \\
\text { Education } \\
\text { (6) }\end{array}$ \\
\hline Linear trend & $\begin{array}{c}0.004 \\
{[0.012]}\end{array}$ & $\begin{array}{c}0.007 \\
{[0.010]}\end{array}$ & $\begin{array}{c}0.006 \\
{[0.010]}\end{array}$ & $\begin{array}{c}-0.015 \\
{[0.017]}\end{array}$ & $\begin{array}{c}0.017 \\
{[0.017]}\end{array}$ \\
\hline Quadratic trend & $\begin{array}{c}0.005 \\
{[0.011]}\end{array}$ & $\begin{array}{c}0.007 \\
{[0.010]}\end{array}$ & $\begin{array}{c}0.007 \\
{[0.010]}\end{array}$ & $\begin{array}{c}-0.017 \\
{[0.017]}\end{array}$ & $\begin{array}{c}0.015 \\
{[0.016]}\end{array}$ \\
\hline Cubic trend & $\begin{array}{c}0.019 \\
{[0.016]}\end{array}$ & $\begin{array}{c}0.021 \\
{[0.013]}\end{array}$ & $\begin{array}{c}0.013 \\
{[0.014]}\end{array}$ & $\begin{array}{c}0.002 \\
{[0.023]}\end{array}$ & $\begin{array}{c}0.009 \\
{[0.022]}\end{array}$ \\
\hline Linear spline & $\begin{array}{c}0.004 \\
{[0.011]}\end{array}$ & $\begin{array}{c}0.007 \\
{[0.010]}\end{array}$ & $\begin{array}{c}0.006 \\
{[0.010]}\end{array}$ & $\begin{array}{c}-0.018 \\
{[0.017]}\end{array}$ & $\begin{array}{c}0.014 \\
{[0.016]}\end{array}$ \\
\hline Quadratic spline & $\begin{array}{c}0.019 \\
{[0.018]}\end{array}$ & $\begin{array}{c}0.025^{*} \\
{[0.015]}\end{array}$ & $\begin{array}{c}0.014 \\
{[0.016]}\end{array}$ & $\begin{array}{c}0.009 \\
{[0.026]}\end{array}$ & $\begin{array}{c}0.009 \\
{[0.025]}\end{array}$ \\
\hline Cubic spline & $\begin{array}{c}-0.019 \\
{[0.024]}\end{array}$ & $\begin{array}{c}0.019 \\
{[0.020]}\end{array}$ & $\begin{array}{c}-0.011 \\
{[0.020]}\end{array}$ & $\begin{array}{c}0.002 \\
{[0.042]}\end{array}$ & $\begin{array}{c}0.021 \\
{[0.035]}\end{array}$ \\
\hline \multicolumn{6}{|l|}{ Cal. month dummies } \\
\hline Sample Size & $\begin{array}{c}Y \\
41,583\end{array}$ & $\begin{array}{c}Y \\
41,655\end{array}$ & $\begin{array}{c}Y \\
41,583\end{array}$ & $\begin{array}{c}\mathrm{Y} \\
8,650\end{array}$ & $\begin{array}{c}\mathrm{Y} \\
6,896\end{array}$ \\
\hline Mean of dep. variable & 0.40 & 0.38 & 0.21 & 0.20 & 0.11 \\
\hline
\end{tabular}

Notes: Robust standard errors in brackets. ***,** and * indicate statistical significance at the 1, 5 and 10 percent level respectively. Samples include cohorts born between January 1, 1956 and December 31, 1961 who graduated from university. AFTER is defined as 1 for individuals born on or after January 1, 1959 and 0 for individuals born on or before December 31, 1958. All regressions include 11 calendar month dummies. 
Appendix Table 1: Robustness checks for eligibility to attend university

\begin{tabular}{ccccc}
\hline Rural Born & Born Poor & Born Rural and & Mother Primary & Father Primary \\
Region & Poor Region & Education & Education
\end{tabular}

(1)

(2)

(3)

(5)

(6)

Panel A: Alternative windows

$\begin{array}{lccccc}1 \text { year window } & 0.045^{* *} & 0.028^{* *} & 0.040^{* * *} & 0.052^{* *} & 0.058^{* * *} \\ & {[0.016]} & {[0.012]} & {[0.012]} & {[0.019]} & {[0.017]} \\ 2 \text { year window } & 0.041^{* * *} & 0.021^{* *} & 0.026^{* * *} & 0.054^{* * *} & 0.051^{* * *} \\ & {[0.006]} & {[0.008]} & {[0.007]} & {[0.012]} & {[0.011]} \\ 4 \text { year window } & 0.042^{* * *} & 0.023^{* * *} & 0.029 * * * & 0.047 * * * & 0.034 * * * \\ & {[0.004]} & {[0.006]} & {[0.005]} & {[0.008]} & {[0.008]}\end{array}$

Panel B: Placebo year cutoffs

\begin{tabular}{lccccc}
1957 & -0.006 & -0.005 & -0.006 & -0.011 & -0.007 \\
& {$[0.006]$} & {$[0.006]$} & {$[0.006]$} & {$[0.011]$} & {$[0.013]$} \\
1958 & 0.009 & -0.004 & -0.004 & 0.003 & -0.002 \\
& {$[0.006]$} & {$[0.007]$} & {$[0.006]$} & {$[0.012]$} & {$[0.011]$} \\
$\mathbf{1 9 5 9}$ & $\mathbf{0 . 0 3 7 * *}$ & $\mathbf{0 . 0 2 2 * *}$ & $\mathbf{0 . 0 2 8 * *}$ & $\mathbf{0 . 0 4 5 * *}$ & $\mathbf{0 . 0 4 0 * *}$ \\
& {$[\mathbf{0 . 0 0 5}]$} & {$[\mathbf{0 . 0 0 7}]$} & {$[\mathbf{0 . 0 0 6}]$} & {$[\mathbf{0 . 0 1 0}$} & {$[\mathbf{0 . 0 0 9}]$} \\
1960 & $-0.012^{*}$ & 0.002 & 0.002 & -0.013 & -0.016 \\
& {$[0.005]$} & {$[0.006]$} & {$[0.006]$} & {$[0.011]$} & {$[0.010]$} \\
1961 & $-0.018^{* *}$ & $-0.016^{* *}$ & $-0.020^{* *}$ & -0.018 & -0.011 \\
& {$[0.005]$} & {$[0.005]$} & {$[0.005]$} & {$[0.011]$} & {$[0.011]$} \\
\hline
\end{tabular}

Notes: Robust standard errors are provided in brackets. ${ }^{* *}$, ** and * indicate statistical significance at the 1, 5 and 10 percent level respectively. Samples include cohorts born three years on either side of the cutoff. All regressions include a quadratic in month of birth and calendar of month dummies, except for the 1 year window which only includes a quadratic in month of birth. AFTER is defined as 1 for individuals born on or after January 1 of the respective year and 0 for individuals born on or before December 31 of the previous respective year. 
Appendix Table 2: Robustness checks for university completion

$\begin{array}{ccccc}\text { Rural Born } & \begin{array}{c}\text { Born Poor } \\ \text { Region }\end{array} & \begin{array}{c}\text { Born Rural and } \\ \text { Poor Region }\end{array} & \begin{array}{c}\text { Mother Primary } \\ \text { Education }\end{array} & \begin{array}{c}\text { Father Primary } \\ \text { Education }\end{array}\end{array}$

$(1)$

$(2)$

(3)

(5)

(6)

\section{Panel A: Alternative windows}

$\begin{array}{cccccc}\text { 1 year window } & 0.014 & 0.025 & 0.018 & -0.004 & 0.021 \\ & {[0.029]} & {[0.018]} & {[0.021]} & {[0.037]} & {[0.031]} \\ \text { 2 year window } & 0.012 & 0.016 & 0.008 & -0.024 & 0.006 \\ & {[0.013]} & {[0.014]} & {[0.012]} & {[0.022]} & {[0.021]} \\ 4 \text { year window } & 0.013 & 0.003 & 0.007 & 0.002 & 0.021 \\ & {[0.009]} & {[0.010]} & {[0.009]} & {[0.015]} & {[0.014]}\end{array}$

Panel B: Placebo year cutoffs

\begin{tabular}{cccccc}
1957 & 0.002 & 0.002 & 0 & 0.015 & 0.01 \\
& {$[0.010]$} & {$[0.010]$} & {$[0.009]$} & {$[0.022]$} & {$[0.019]$} \\
1958 & 0.013 & -0.01 & -0.006 & 0.024 & -0.005 \\
& {$[0.011]$} & {$[0.012]$} & {$[0.011]$} & {$[0.019]$} & {$[0.018]$} \\
$\mathbf{1 9 5 9}$ & $\mathbf{0 . 0 0 5}$ & $\mathbf{0 . 0 0 7}$ & $\mathbf{0 . 0 0 7}$ & $-\mathbf{0 . 0 1 7}$ & $\mathbf{0 . 0 1 5}$ \\
& {$[\mathbf{0 . 0 1 1}]$} & {$[\mathbf{0 . 0 1 0}]$} & {$[\mathbf{0 . 0 1 0}]$} & {$[\mathbf{0 . 0 1 7}$} & {$[\mathbf{0 . 0 1 6}]$} \\
1960 & -0.01 & -0.002 & 0.004 & 0.004 & 0.014 \\
& {$[0.009]$} & {$[0.012]$} & {$[0.010]$} & {$[0.017]$} & {$[0.016]$} \\
1961 & 0.005 & 0.001 & 0 & -0.003 & $-0.039 * *$ \\
& {$[0.010]$} & {$[0.010]$} & {$[0.009]$} & {$[0.015]$} & {$[0.013]$} \\
\hline
\end{tabular}

Notes: Robust standard errors are provided in brackets. ***, ** and * indicate statistical significance at the 1, 5 and 10 percent level respectively. Samples include cohorts born three years on either side of the cutoff. All regressions include a quadratic in month of birth and calendar of month dummies, except for the 1 year window which only includes a quadratic in month of birth. AFTER is defined as 1 for individuals born on or after January 1 of the respective year and 0 for individuals born on or before December 31 of the previous respective year. 